\title{
Теоретико-методологічні основи психофізичної підготовки студентів інженерних спеціальностей у процесі фрізичного виховання
}

\author{
Наталія Москаленкоㄹ, Валерій Пічурін²
}

1 Придніпровська державна академія фізичної культури і спорту, Дніпро, Україна

2 Дніпровський національний університет залізничного транспорту імені академіка В. Лазаряна, Дніпро, Україна

Анотація. До сьогодні у сфері освіти домінує спрощена думка, відповідно до якої професійн знання є основою професійної підготовки, а інші сторони покликані обслуговувати їх освоєння. У той самий час звичними стають претензії до психофізичної підготовленості фахівця (багато, наприклад, говориться про так званий людський фактор у зв'язку 3 аварійністю). Проте в загальній підготовці інженера як такій місця для психофізичної підготовки немає. Таким чином, спостерігається розрив між вимогами практики і реаліями підготовки інженера. Мета. Науково обґрунтувати та розробити теоретико-методологічні основи психофізичної підготовки студентів інженерних спеціальностей у процесі фрізичного виховання (на прикладі закладів вищої освіти залізничного транспорту) для підвищення рівня їх готовності до професійної діяльності в умовах виробництва. Методи. Вивчення та аналіз літературних джерел, опитування, педагогічне спостереження, педагогічне тестування, педагогічний експеримент, методи психологічної діагностики, методи математичної статистики. Результати. Теоретично узагальнено й подано авторський підхід до вирішення проблеми професійно орієнтованої психофізичної підготовки студентів інженерних спеціальностей у процесі фрізичного виховання. В рамках підходу обґрунтовано й розроблено концепцію психофізичної підготовки студентів закладів вищої освіти залізничного транспорту. Доведено есрективність реалізації у процесі викладання навчальної дисципліни «Фізичне виховання» авторської концепції. Запропоновано нове вирішення проблеми професійно-орієнтованої психофізичної підготовки студентів інженерних спеціальностей у фізичному вихованні.

Ключові слова: фізичне виховання, студенти, професійно значущі якості, увага, тривожність копінг-стратегії.

\section{Natalia Moskalenko, Valerii Pichurin}

\section{THEORETICO-METHODOLOGICAL BASES OF PSYCHOPHYSICAL PREPARATION OF ENGINEERING STUDENTS IN THE PROCESS OF PHYSICAL EDUCATION}

Abstract. To date, the field of education is dominated by a simplistic view, according to which professional knowledge is the basis of professional training, and other parties are called to serve their mastering. At the same time, claims to the psychophysical fitness of a specialist are becoming commonplace (for instance, much is said about the so-called human factor in connection with accidents). However, in the general training of the engineer as such there is no place for psychophysical training. Thus, there is a gap between the requirements of practice and the realities of engineer training. Objective. Scientifically substantiate and develop theoretical and methodological foundations of psychophysical training of engineering students in the process of physical education (on the example of higher education institutions of railway transport) to increase their readiness for professional activity in production. Methods. Study and analysis of literature sources, surveys, pedagogical observation, pedagogical testing, pedagogical experiment, methods of psychological diagnostics, methods of mathematical statistics. Results The author's approach to solving the problem of professionally oriented psychophysical training of engineering students in the process of physical education is theoretically generalized and presented. Within the framework of the approach, the concept of psychophysical training of students of higher education institutions of railway transport is substantiated and developed. The effectiveness of the author's concept in the process of teaching the discipline «Physical Education» is proved. A new solution to the problem of professionally-oriented psychophysical training of engineering students in physical education is proposed.

Keywords: physical education, students, professionally significant qualities, attention, anxiety, coping strategies.
Москаленко Н., Пічурін В. Теоретикометодологічні основи психофізичної підготовки студентів інженерних спеціальностей у процесі фрізичного виховання. Теорія і методика фрізичного виховання і спорту. 2021; 1: 82-89 DOI: 10.32652/tmfvs.2021.1.82-89
Вступ. На сьогодні проблема фрізичного виховання в закладах вищої освіти (ЗВО) досить актуальна, про що свідчить велика кількість наукових досліджень [1, 10, 12, 26, 31, 33]. Учені $[6,15,21,24,31,34-36]$ доходять висновку, що існуюча система фізичного виховання студентів малоефективна й не забезпечує достатнього рівня фізичної, психологічної та професійної готовності випускників до виробничої діяльності, а тому стає першочерговим завдання її вдосконалення.

Однією з головних складових підготовки студентів у ЗВО є профресійноприкладна фізична підготовка, яка сприяє формуванню фізичних і психічних якостей, рухових навичок, необхідних для майбутньої професії. Формування загальної концепції й теоретико-методичне обґрунтування концептуальних основ професійноприкладної фізичної підготовки студентів 3 ВО здійснив Л. П. Пилипей [17]. Найбільш розробленою є проблематика, пов'язана 3 професійноприкладною фрізичною підготовкою за окремими спеціальностями, зокрема: технічними [22, 27, 32]; транспортними [20, 23, 28]; інфрормаційно-логічної групи [14]; гірничодобувного профілю [4]; економічними [5, 16]; військовими [9, 13, 30]; агропромислового виробництва [8]; екологічними [3]; за напрямом «мікро- та наноелектроніка» [11]; мистецьких спеціальностей [1, 29]. Водночас у наукових дослідженнях не приділяється достатньої уваги науковому обґрунтуванню психофізичної підготовки студентів, що передбачає формування ряду професійно значущих рис особистості, психічних процесів (увага, сприйняття, пам'ять, мислення, уява) та психомоторики (вестибулярна стійкість, швидкість у діях, сенсомоторні реакції). Саме від рівня розвитку цих характеристик багато в чому залежить результативність виконання майбутніми фахівцями професійних функцій. 
Певні аспекти психофрізичної підготовки студентів до професійної діяльності у рамках фрізичного виховання були предметом дослідження окремих науковців. Зокрема, 0. 0. Єгоричев [7] розробив і експериментально перевірив технологію управління психофрізичною підготовкою студентів до профресійної діяльності, І. А. Бікмаєв [2] дослідив проблему професійної психофрізичної підготовки студентів спеціальності «Безпека життєдіяльності». Проте слід зауважити, що комплексному підходу до психофізичної підготовки студентів у процесі фізичного виховання до подальшої виробничої діяльності не приділялося достатньої уваги. Тому проблема наукового обгрунтування та розробки теоретико-методологічних основ психофізиичної підготовки студентів у процесі фізичного виховання $є$ актуальною.

Мета дослідження - науково обгрунтувати та розробити теоретикометодологічні основи психофрізичної підготовки студентів інженерних спеціальностей у процесі фрізичного виховання (на прикладі закладів вищої освіти залізничного транспорту) для підвищення рівня їх готовності до професійної діяльності в умовах виробництва.

Методи дослідження: вивчення та аналіз літературних джерел, опитування, педагогічне спостереження, педагогічне тестування, педагогічний експеримент, методи психологічної діагностики, методи математичної статистики.

Результати дослідження та їх обговорення. У дослідженні брали участь студенти Дніпровського національного університету залізничного транспорту імені академіка В. Лазаряна. Загальна кількість учасників констатуючого експерименту становила 600 осіб, з них 522 - юнаки, 78 - дівчата. У формувальному експерименті брали участь 318 студентів, 3 них 258 - юнаки, 60 - дівчата. Від усіх учасників було отримано інфоормовану згоду на участь в експерименті.

Процедура дослідження передбачала: а) на першому етапі - визначити теоретико-методологічні, професійні та педагогічні передумови прове- дення психофізичної підготовки у фізичному вихованні; б) на другому етапі (на основі даних попереднього етапу) - розробити концепцію психофрізичної підготовки студентів у фізичному вихованні; в) на третьому - провести експериментальну перевірку ефективності запропонованої концепції.

Під час вирішення завдань першого етапу виходили 3 того, що теорія і методика фрізичного виховання пов'язана з багатьма іншими науками, спирається на відкриті ними закономірності, використовує їхні здобутки. Як зазначають фрахівці [25], вона вирішує спеціальні педагогічні проблеми, що виникають на стику кількох наукових дисциплін. Виходячи 3 таких міркувань, для вирішення питання про теоретико-методологічне обгрунтування концепції психосрізичної підготовки в процесі фізичного виховання було зроблено спробу знайти відповідь у сфрерах фрілософії і психології. Вихідним положенням дослідження стало таке припущення. Оскільки фрізичне виховання безпосередньо пов'язане із впливом на організм людини, а психофізична підготовка спрямована головним чином на психічні складові, необхідно виконати аналіз тих філософсььких і психологічних питань, які прямо пов'язані 3 предметом дослідження, а саме: психосрізична проблема, взаємовплив організму та психіки, уявлення про особистість.

Аналіз теоретичних підходів до розуміння психосрізичної проблеми дає підстави зробити висновок про те, що в сучасній психології загальновизнаним $є$ положення про взаємовплив організму та психіки людини. Це положення надзвичайно важливе для фрізичного виховання саме в контексті вирішення завдань реалізації психофрізичної підготовки. Дослідження прихильників організмічної теорії в психології (К. Гольдштейн, Р. Уілер, Х. Уернер); психоаналізу (3. Фрейд, К. Г. Юнг, А. Адлер, К. Хорні); психосоматичного підходу в медицині (Е. Данбар, Г. Бергман, А. Йорес); теорії психології розвитку (Г. Крайг); тілесно-орієнтованої психотерапії (В. Райх, А. Лоуен, І. Рольфф, А. Янов) дають підстави фахівцям 3 фізичного виховання зробити припущення про те, що, впливаючи на організм людини (використовуючи фізичні вправи), можна формувати складові її психічної структури. Прийняття такої методологічної позиції створює основу для розуміння процесів формування у фрізичному вихованні таких психофізичних складових, як особистість людини, пізнавальні процеси, емоційно-вольова сфера, що дозволяє цілеспрямовано впливати на підвищення відповідної підготовленості студентів.

Поза межами психофрізичної проблеми взаємозв'язок організму і психіки людини також вивчався в різних наукових напрямах. Теоретичний аналіз свідчить про визнання цього явища у філософії, психології, медицині. Прикладами є: розгляд у філософії тілесності як умови можливості бути і самовизначитись як особистості; зафріксований психологами вплив тілесного досвіду хронічного соматичного захворювання на зміну структури суб'єктивної картини життєвого шляху особистості; отримані дані про оцінювання індивідуально-психологічних характеристик незнайомої людини за фоотозображенням ії обличчя; визнання психотерапевтами того фракту, що тілесна конституція перебуває в гармонії з психікою людини; зафріксовані фракти фрізичних реакцій на суб'єктивний стан особистості людини. Ці дані доповнюють результати аналізу досліджень психофрізичної проблеми і також дають підстави констатувати взаємну залежність і взаємний вплив організму і психіки людини. Для фахівців з фізичного виховання це є ще одним джерелом даних, необхідних для обгрунтування доцільності використання засобів фізичного виховання для формування психічних складових. На сьогодні ґрунтовно досліджено можливості фрізичного виховання впливати на організм людини. Водночас його можливості стосовно розвитку психіки $є$ такими, що вивчені недостатньо.

Фахівці обґрунтовано ставлять питання про підвищення освітнього й виховного потенціалу фрізичного виховання у формуванні особистості сучасного спеціаліста (М. Я. Вілен- 
ський, Л. І. Лубишева, В.В.Приходько, Т. Ю. Круцевич, С. М. Футорний, Н. В. Москаленко). Викладач фрізичного виховання, як і педагог будь-якого іншого профрілю, повинен бути добре обізнаним з усіма сторонами й характеристиками особистості, зі способами її формування і розвитку. Повною мірою це стосується і вирішення завдань психофрізичної підготовки студентів під час навчального процесу 3 фізичного виховання у ЗВО, оскільки вона безпосередньо пов'язана з впливом на структурні компоненти особистості. Знання існуючих у психології уявлень про особистість, про її психологічні, соціальні, біологічні витоки, про структуру і динаміку особистості створює теоретичні передумови для наукової розробки ефективних шляхів формування психосрізичної підготовленості майбутнього фахівця.

Профресійними передумовами створення концепції психофрізичної підготовки студентів ЗВО залізничного транспорту у фрізичному вихованні $€$ вимоги до інженерних професій працівників цієї галузі. Вони ґрунтуються на кваліфікаційних характеристиках основних інженерних професій, в яких наведено якості, що сприяють або перешкоджають успішному виконанню професійної діяльності. Основну увагу необхідно звернути на формування емоційної стійкості, оперативного мислення, концентрації та стійкості уваги.

Педагогічною передумовою необхідності вдосконалення процесу психофрізичної підготовки майбутніх фрахівців $€$ сучасний стан організації фрізичного виховання у ЗВО. Аналіз нормативних документів свідчить, що в системі фрізичного виховання студентів останнім часом започатковано зміни у зв'язку з документами, прийнятими МОН України, а саме лист Мiністерства освіти і науки України від 13.03.2015 № 1/9-126 «Щодо особливостей організації освітнього процесу та формування навчальних планів у 2015/2016 навчальному році» та лист від 25.09.2015 № 1/9-454 «Щодо організації фізичного виховання у вищих навчальних закладах». Зазначені в цих документах рекомендації закладам вищої освіти щодо викладан- ня фрізичного виховання як навчальної дисципліни (вибірковість вивчення, відсутність заліку) по суті виводять фрізичне виховання за межі навчального процесу. Це може призвести до суттєвого зниження рівня фрізичних якостей та психологічних характеристик студентів, що, в свою чергу, неми нуче негативно позначиться на їхній загальній готовності до професійної діяльності. Реалізація психофрізичної підготовки до професійної діяльності $€$ важливим аргументом збереження фізичного виховання як навчальної дисципліни.

Результати, отримані в процесі аналізу теоретико-методологічних, професійних та педагогічних передумов, стали теоретичним підґрунтям для розробки концепції психофрізичної підготовки студентів ЗВО залізничного транспорту у процесі фрізичного виховання [18, 19].

Суть авторської концепції полягає в комплексному підході до фрізичного виховання студентів 3В0, у процесі якого вирішується блок завдань, одним із яких $€$ фрормування психофрізичної підготовленості студентів до майбутньої просесійної діяльності Поняття «психофрізична підготовка» трактується у цьому дослідженні як складова фрізичного виховання, спеціалізована відносно психологічних і психофрізичних особливостей майбутньої професійної діяльності студентів.

Структуру авторської концепції психофрізичної підготовки утворюють такі складові: передумови (теоретикометодологічні, професійні, педагогічні); мета концепції; принципи, на основі яких реалізується концепція; ссрери психофрізичної підготовленості майбутніх фрахівців, на які здійснюється вплив; організаційно-педагогічні умови реалізації концепції; етапи впровадження концепції; компоненти готовності майбутніх фрахівців; критері ефрективності концепції.

Мета концепції - теоретично обґрунтувати, розробити і практично реалізувати організаційно-методичні основи психофрізичної підготовки студентів 3В0 залізничного транспорту в процесі фізичного виховання для підвищення рівня готовності до професійної діяльності.
Розроблені організаційно-педагогічні умови втілення концепції психосрізичної підготовки у практику фрізичного виховання включають: створення системи залучення студентів до занять, орієнтованих на психофрізичну підготовку; створення умов для психосрізичної самопідготовки студентів у позаурочний час; інфрормаційнометодичне забезпечення занять; підготовку викладачів до організації занять, спрямованих на психофрізичну підготовку; розробку програми психофрізичної підготовки студентів. Психофрізична підготовка забезпечує: постановку в навчальному процесі відповідних завдань, реалізацію відповідного змісту навчальних занять 3 фрізичного виховання, контроль результатів проведеної роботи.

Для забезпечення виконання цих вимог розроблено зміст і тематику теоретичного розділу з психофізичної підготовки студентів; зміст практичних занять; програму семінару для викладачів фрізичного виховання.

Реалізація розроблених організаційно-методичних засад психофрізичної підготовки у процесі фрізичного виховання студентів відбувалась у три етапи - підготовчий, основний і контрольний. Завданнями підготовчого етапу були: підготовка науковопедагогічних працівників до організації та проведення психофізичної підготовки студентів у процесі фрізичного виховання; обґрунтування змісту занять 3 фрізичного виховання зі студентами; формування у студентів позитивної мотивації до підвищення власного рівня психофрізичної підготовленості до професійної діяльності.

Другий етап - основний. Його завданнями були: 1) впровадження засобів психофрізичної підготовки в навчальний процес з фрізичного виховання; 2) формування у студентів профресійно значущих психофрізичних якостей; 3) підвищення теоретикометодичних знань студентів у сфері психофрізичної підготовленості; 4) фрормування у студентів практичних умінь і навичок використання засобів психофрізичної підготовки у процесі самостійних занять. Організація цієї роботи передбачала проведення 
Т а б л и ц я 1. Розподіл годин програми психофрізичної підготовки студентів закладів вищої освіти залізничного транспорту

\begin{tabular}{|c|c|c|c|}
\hline \multirow{2}{*}{ Зміст занять, кількість навчальних годин } & \multicolumn{2}{|c|}{ Курс } & \multirow{2}{*}{ Beborc } \\
\hline & I & II & \\
\hline Теоретичні заняття & 10 & 8 & 18 \\
\hline \multicolumn{4}{|l|}{ Практичні заняття: } \\
\hline Заняття професійно значущим видом спорту & 72 & 74 & 146 \\
\hline $\begin{array}{l}\text { Виконання спеціальних фізичних вправ для розвитку психофізичних якостей } \\
\text { і вправ для формування навичок саморегуляції психічного стану }\end{array}$ & 22 & 22 & 44 \\
\hline Навчальні змагання з професійно значущих видів спорту & 16 & 16 & 32 \\
\hline Контрольні заходи & 8 & 8 & 16 \\
\hline Всього & 128 & 128 & 256 \\
\hline
\end{tabular}

відповідної спеціалізованої підготовки у навчальний час.

Третій етап - контрольний. Завданнями, які вирішувались на цьому етапі, були: оцінювання рівня сформованості професійно значущих психофрізичних якостей студентів, фрізичної та теоретичної підготовленості 3 фізичного виховання. Передбачався щосеместровий контроль психофрізичної підготовленості (у першому-четвертому семестрах).

На основі аналізу професійних характеристик залізничних спеціальностей і специфіки конкретних видів спортивної діяльності визначено професійно значущі види спорту.

У структурі психофрізичної готовності до професійної діяльності можна виділити такі компоненти готовності: мотиваційний, особистісний, когнітивний, операційний, фрізичний. Мотиваційний компонент передбачає сформованість мотивації до покращення власної психофрізичної готовності. Така мотивація формується у студентів у ході основного і підготовчого етапів впровадження психофрізичної підготовки з використанням, насамперед, блоку психологічної просвіти. Завдяки включенню його до засобів психофізичної підготовки у студентів формується розуміння її місця і ролі в структурі їх загальної готовності до професійної діяльності. Це сприяє усвідомленому виконанню студентами навчальних завдань, підвищує їх відповідну активність у позанавчальний час.
Особистісний компонент психофізичної готовності до професійної діяльності передбачає сформованість у студентів професійно значущих якостей особистості, підвищення рівня розвитку уваги, складових психомоторики. Цей компонент відіграє вирішальну роль під час визначення рівня психофізичної підготовленості студентів. Переважна більшість засобів психофрізичної підготовки, спрямована саме на формування особистісного компонента.

Когнітивний компонент характеризує рівень знань, спрямованих на підвищення рівня психофізичної підготовленості. Достатній рівень знань створює передумови для самостійних занять у майбутньому.

Операційний компонент характеризує рівень психофізичної підготовленості студентів з позиції досягнутого рівня сформованості практичних умінь і навичок підтримання власної психофрізичної готовності. Це, насамперед, уміння і навички зі сфери професійно значущих видів спорту. Важливими $є$ і сформовані уміння і навички самостійного використання спеціальних фрізичних вправ для розвитку психомоторики, вправ для саморегуляції психічного стану й зниження наслідків стресу. Фізичний компонент передбачає сформованість у студентів фізичних якостей, які $€$ найбільш значущими для майбутньої професійної діяльності.

У структурі концепції психофізичної підготовки передбачено розробку програм психофрізичної підготовки для студентів різних спеціальностей, до яких включено: тематику і зміст теоретичного розділу з психофізичної підготовки студентів; зміст практичних занять.

Розподіл навчальних годин програми психофрізичної підготовки студентів ЗВО залізничного транспорту наведено в таблиці 1.

Розроблено загальну структуру програм психофрізичної підготовки для студентів спеціальностей «0pганізація перевезень і управління на залізничному транспорті», «Вагони та вагонне господарство», «Локомотиви та локомотивне господарство»; «Електричний транспорт», «Електромеханічні системи автоматизації та електропривід»; «Залізничні споруди та колійне господарство». «Мости і транспортні туннелі».

Представлена концепція надає можливість цілеспрямовано управляти процесом психофрізичної підготовки студентів під час занять фрізичними вправами.

Формувальний експеримент проводили 3 метою визначення ефективності концепції психофізичної підготовки для вирішення завдань фрормування у студентів згаданих спеціальностей ряду професійно значущих характеристик. Тривалість експерименту становила два навчальних роки (I, II курси навчання в обсязі 4 навчальні години на тиждень). Результати свідчать, що впровадження концепції сприяє підвищенню рівня фрізичної підготовленості студентів. В експериментальних групах зафіксовано 
зростання результатів у таких тестах «біг 100 м» $(p<0,01)$; «біг 3000 м» $(p<0,01)$; «нахил вперед з положення сидячи» ( $p<0,01)$; «підтягування на перекладині» $(p<0,01)$; «піднімання тулуба в сід за одну хвилину» ( $<<0,01)$; «стрибок у довжину 3 місця» $(p<0,01)$. При цьому слід зазначити, що статистично значущі відмінності показників у експериментальних групах виявлено за всіма видами випробувань. У контрольній групі статистично значуща позитивна динаміка виявлена тільки за результатом виконання тесту «нахил вперед з положення сидячи» $(p<0,05)$.

За результатами дослідження доведено, що впровадження концепції психофрізичної підготовки студентів різних спеціальностей сприяло формуванню у них профресійно значущих рис (факторів) особистості, адаптивних і відносно адаптивних когнітивних і поведінкових копінг-стратегій, толерантності до невизначеності, зниженню високих показників особистісної тривожності.

Після закінчення експерименту у студентів експериментальної групи було виявлено достовірно вищий рівень сфрормованості таких складових особистості (за Р. Кеттеллом): «емоційна нестійкість-емоційна стійкість» ( $p$ < 0,05); «схильність до почуттів-висока нормативність поведінки» ( $>$ < 0,01); «впевненість у собі-тривожність» $(p<0,05)$; «низький самоконтроль-високий самоконтроль» $(p<0,01)$; «адекватність самооцінки» $(p<0,01)$. У контрольній групі статистично значущих змін не відбулось.

В усіх експериментальних групах покращилися показники використання студентами адаптивних і відносно адаптивних когнітивних і поведінкових копінг-стратегій $(p<0,05)$. При цьому найбільш суттєві позитивні зрушення у фрормуванні адаптивних і відносно адаптивних когнітивних і поведінкових копінг-стратегій виявлено в експериментальній групі № 3 (спеціальності «Електричний транспорт», «Електромеханічні системи автоматизації та електропривід» $(p<0,01))$. у контрольній групі статистично значущих змін не виявлено. Водночас слід зазначити, що нами не встановлено дієвість концепції фрормування адаптивних і відносно адаптивних емоційних копінг-стратегій ( $p>0,05)$.

Виявлено достовірне покращення таких складових толерантності до невизначеності, як «сміливість, підприємливість» $(p<0,01)$, «адаптивність» $(p<0,01)$, «толерантність до двозначності» $(p<0,01)$. У контрольній групі статистично значущих змін не відбулось. Спостерігали ефективність застосування у фрізичному вихованні концепції психофрізичної підготовки для зниження високих показників особистісної тривожності у студентів. В експериментальній групі юнаків 3 високим рівнем особистісної тривожності зниження відбулось на рівні $p<0,01$. В аналогічній контрольній групі статистично значущих змін не відбулось. В експериментальній групі дівчат з високим рівнем особистісно тривожності зниження відбулось на рівні $p<0,01$, в контрольній групі статистично значущих змін не відбулось.

Встановлено, що реалізація концепції психофрізичної підготовки сприяла розвитку в студентів концентрації і стійкості уваги, а також вестибулярної стійкості. Так, після закінчення експерименту в усіх експериментальних групах у студентів зафріксовано суттєве зростання рівня розвитку цих складових уваги $(p<0,01)$. При цьому найбільш суттєві позитивні зрушення було зафріксовано в експериментальній групі № 1 спеціальності «Організація перевезень і управління на залізничному транспорті». У контрольній групі суттєвого зростання показ ників концентрації і стійкості уваги не зафріксовано ( $p>0,05)$.

Результати, отримані в експериментальних групах після закінчення експерименту, свідчать про ефективність концепції психофрізичної підготовки для розвитку в студентів вестибулярної стійкості $(p<0,01)$. Найбільш суттєвий позитивний вплив на розвиток цієї складової координаційних здібностей заффіксовано в експериментальній групі № 5 спеціальності «Мости і транспортні тунелі», у контрольній групі статистично значущих змін не відбулось.

Дискусія. Аналіз показує, що у фізичному вихованні підготовка до про- фесійної діяльності зазвичай обмежується професійно-прикладною фрізичною підготовкою. У рамках цього напряму проведено велику кількість досліджень, у яких головну увагу зосереджено на вдосконаленні прикладної фрізичної підготовленості фрахівця. Водночас досліджень, у яких вивчалися питання формування у сфері фрізичного виховання психологічних і психофізичних характеристик, одиниці.

У науковій літературі фрахівцями використовуються такі поняття, як «психологічна підготовка», «психофізична підготовка», «психофізіологічна підготовка». Аналіз показує, що психологічна підготовка розглядається ученими як: а) комплекс спеціалізованих заходів; б) процес фрормування особистості до умов певної діяльності; в) психологічне налаштування людини на виконання певної діяльності. Зміст поняття «психофрізична підготовка» вони також визначають по-різному. Так, деякі із них трактують психофрізичну підготовку, по суті, як фрізичну і зводять їі до розвитку спритності (І. М. Туревський). Інші використовують поняття для поєднання в одній системі підсистем фрізичної і психологічної готовності (0. 0. Єгоричев) або ототожнюють психофрізичну і професійно-прикладну фізичну підготовку (В. І. Ільїніч). Поняття «психофізіологічна підготовка» пов'язується 3 використанням комплексу спеціально застосовуваних засобів, інтегративний вплив яких призводить до формування у фрахівців системи нервових зв'язків, які утворюють спеціалізовані динамічні стереотипи.

У цьому дослідженні психофізична підготовка студентів розглядається як частина фрізичного виховання, спеціалізована відносно психологічних і психофрізичних особливостей їх майбутньої профресійної діяльності. Такий підхід обумовлений тим, що фрізкультурна діяльність $€$ ефективною як для формування психологічних складових (наприклад, рис особистості), так і для розвитку психофрізичних характеристик (наприклад, складових психомоторики). У такій ситуації немає сенсу розділяти ці види підготовки в 
процесі навчальних занять 3 фрізичного виховання.

У ході нашого дослідження отримано три групи даних. Підтверджено дані про значення фрізичного виховання у підготовці фрахівців до професійної діяльності (0. О. Єгоричев; О. І. Подлесний; І. Г. Бондаренко; Л. П. Пилипей; В. О. Садовський; О. М. Ольховий; С. М. Футорний; Ю. О. Доценко; Ю. О. Остапенко; Н. Є. Пангелова; T. В. Людовик; V. Kashuba; I. Asauluk, A. Dyachenko; Є. О. Карабанов; B. 0. Кашуба; V. Chernii, 0. Shevchenko, 0. Nievorova, A. Melnyk, A. Kramarenko, T. Nikonenko); про низький рівень фрізичної підготовленості сучасних студентів (Л. П. Пилипей; Л. Долженко; О. Я. Дубинська; Н. В. Петренко; Н. В. Москаленко; І. П. Випасняк; І. О. Асаулюк).

Отримали подальший розвиток наукові дані про формування психічних характеристик у фрізкультурній діяльності (В. Л. Маріщук; Д. О. Петров; О. В. Пристав; А. Г. Саракул; В. С. Хагай; Ю. І. Родін; С. В. Галіцин; В. М. Шебеко; Н. Є. Пангелова); про фрормування особистості у фрізкультурній діяльності (0. І. Головченко; Є. Г. Матвеєв; В. Ю. Солонський); про ефективність засобів фрізичної культури для розвитку вестибулярної стійкості (О. У. Холтобіна; В. Г. Стрілець; В. Л. Ботяєв; В. А. Климачов; Г. В. Бикова; І. П. Масляк; Д. В. Сишко; В. А. Романенко; Н. О. Чертихіна); про використання копінг-стратегій представниками різних груп населення (С. А. Хазова; О. І. Склень; І. В. Шагарова; В. І. Воронова; 0. В. Шевяков); рівень теоретичної підготовленості 3 фрізичної культури студентів (0. Андрєєва, У. Катерина; V. Kashuba, I. Asauluk, A. Dyachenko; Y. Imas, M. Dutchak, O. Andrieieva, V. Kashuba, I. Kensytska, 0. Sadovskyi).

Вперше 3 позиції дослідження теоретико-методологічних, професійних та педагогічних передумов здійснено обґрунтування психофрізичної підготовки як складової фрізичного виховання студентів ЗВО залізничного транспорту, спрямованої на вирішення завдань підвищення готовності до професійної діяльності. Науково обґрунтовано та розроблено кон- цепцію психофрізичної підготовки студентів ЗВО залізничного транспорту, спрямованої на підвищення рівня готовності студентів до професійної діяльності. Структурними елементами концепції є: передумови, мета, завдання, принципи, напрями впливу на сфреру психосрізичної підготовленості, організаційно-педагогічні умови, етапи впровадження, визначені компоненти готовності та критерії ефективності. Запропоновано новий підхід до визначення змісту поняття «психофізична підготовка», яка розглядається як частина (сторона) фрізичного виховання, спеціалізована відносно психологічних і психофрізичних особливостей майбутньої професійної діяльності студентів. Під час порівняльного аналізу сформованості складових особистості студентів, які займаються в основному та спортивному відділеннях, встановлено, що у студентів спортивного відділення відбувається більш інтенсивне формування ряду професійно значущих для залізничного транспорту фракторів особистості, порівняно зі студентами основного відділення, що пов'язано з більш високим рівнем загальної та спеціальної фрізичної підготовленості.

Доведено залежність між фрізичною і психофрізичною підготовленістю студентів, яка виявляється в тому, що зростання загального рівня їх фрізичної підготовленості (особливо координаційних здібностей) сприяє покращенню показників вибірковості, концентрації та стійкості уваги, а також - зниженню рівня особистісної тривожності. Виявлено суттєвий позитивний вплив засобів психофізичної підготовки в процесі фрізичного виховання на формування у студентів ряду професійно значущих рис особистості (емоційної стійкості, високої нормативності поведінки, впевненості в собі, високого рівня самоконтролю, адекватності самооцінки), адаптивних і відносно адаптивних когнітивних і поведінкових копінг-стратегій, таких складових толерантності до невизначеності, як «сміливість, підприємливість», «адаптивність», «толерантність до двозначності», зниження високого рівня особистісної тривожності.
Висновки. Дослідження теоретикометодологічних основ психофізичної підготовки студентів інженерних спеціальностей у процесі фрізичного виховання пов'язане 3 необхідністю вирішення як практичних, так і теоретичних питань. Практичні пов'язані 3 необхідністю реагувати в системі освіти на постійно зростаючі вимоги виробництва до цієї складової загальної підготовки фахівців, теоретичні - 3 відсутністю достатнього наукового доробку в теорії і практиці фрізичного виховання у формуванні у цій сфері професійно значущих психофізичних характеристик. Запропонований підхід доцільно розглядати як варіант вирішення зазначених завдань.

Перспективи подальших досліджень полягають у розробці основ психофрізичної підготовки для спеціальностей комунікативної, творчообразної, інформаційно-логічної, природничо-аграрної та екстремальної груп.

Конфлікт інтересів. Автори заявляють, що відсутній будь-який конфллікт інтересів.

\section{ЛITEPATУРA}

1. Асаулюк IO. Теоретико-методичні основи професійно-прикладної фізичної підготовки студентів мистецьких спеціальностей [дисертація] Київ. 2020. 562 с.

2. Бикмаев ИА. Профессиональная психофизическая подготовка студентов специально сти «безопасность жизнедеятельности» в физкультурных вузах [диссертация] Омск. 2004 195 c.

3. Бондаренко ІГ. Засоби професійноприкладної фрізичної підготовки у фрізичному вихованні студентів-екологів [автореферат]. Дніпропетровськ. 2009. 20 с.

4. Доценко ЮО. Оцінка психофрізичної готовності студентів ВН3 гірничодобувного профілю до трудової діяльності [автореферат]. Київ. 2015. 24 с.

5. Дубинська ОЯ, Салатенко IO. Прикладн проблеми фрізичного виховання студентів економічних спеціальностей. В: Єрмаков СС редактор. Педагогіка, психологія та медикобіологічні проблеми фізичного виховання спорту: зб. наук. праць. 2014;(5):19-23.

6. Дутчак М, Андрєєва 0, Катерина У. Зарубіжний досвід організації фрізичного виховання студентів країн, які мають високий рівень залучення населення до оздоровчої рухово активності. Теорія і методика фрізичного вихо вання і спорту. 2018;(3):49-58.

7. Егорычев АО. Теория и технология управления психофизической подготовкой студентов к профессиональной деятельности [диссертация] Ярославль. 2005. 317 с.

8. Карабанов Є0. Оптимізація професійноприкладної фрізичної підготовки майбутніх 
фахівців агропромислового виробництва [авто реферат]. Дніпро. 2017. 22 с.

9. Кирпенко ВМ. Динаміка змін рівня професійно важливих якостей курсантів ви щих військових навчальних закладів льотного профрілю. В: Єрмаков СС, редактор. Педагогіка, психологія та медико-біологічні проблеми фізичного виховання і спорту: зб. наук. праць. 2015;(6):10-3.

10. Круцевич Т, Пангелова Н. Сучасн тенденції щодо організації фрізичного виховання у вищих навчальних закладах. Спортивний вісник придніпров'я. 2016;(3):109-14.

11. Людовик ТВ. Професійно-прикладна фрізична підготовка студентів, які навчаються за освітнім напрямом «мікро- та наноелектроніка [авторесрерат]. Львів. 2016. 19 с

12. Москаленко НВ. Технологія формування ціннісного ставлення у студентів до самостійних занять фізичною культурою. Спортивний вісник Придніпров'я. 2016;(1):201-6.

13. Ольховий ОМ. Теоретико-методичні засади системи фрізичної підготовки курсантів вищих військових навчальних закладів [автореферат]. Київ. 2013. 38 c.

14. Остапенко ЮО. Просесійно-прикладна фрізична підготовка студентів інформаційно логічної групи спеціальностей [авторефрерат] Київ. 2015. 22 с.

15. Пангелова Н, Захарченко Г. Особливості мотивів і потреб студентів у заняттях різновидами ігрових видів спорту. Спортивний вісник Придніпров'я. 2011;(2):48-50.

16. Петренко НВ. Оптимізація фрізично та розумової працездатності студентів еконо мічних спеціальностей засобами аквафітнесу [дисертація]. Київ. 2015. 243 с

17. Пилипей ЛП. Теоретико-методичні осно ви професійно-прикладної фрізичної підготовки студентів вищих навчальних закладів [авторе ферат]. Київ. 2011. 40 c.

18. Пічурін ВВ. Психологічна і психофізична підготовка як складова фізичного виховання студентів вищих навчальних закладів. В Єрмаков СС, редактор. Педагогіка, психологія та медико-біологічні проблеми фіз. виховання і спорту: зб. наук. праць. 2014;(11):44-8. Doi: 10.15561/18189172.2014.1108

19. Пічурін ВВ. Теоретико-методологічн основи психофізичної підготовки студентів інженерних спеціальностей в процесі фізичного виховання. Дніпро: Свідлер А.Л.; 2017. 393 с.

20. Подлесний ОІ. Самоконтроль у фізичному вихованні як засіб підвищення мотивації до професійно-прикладної фрізичної підготовки студентів-судноводіїв [автореферат]. Київ. 2008. 22 C.

21. Приходько ВВ. Про потребу визна чення місця фізичного виховання у ресрорм вітчизняної вищої школи у контексті компе тентнісного підходу. Спортивний вісник Придніпров'я. 2016;(1):215-20.

22. Раевский РТ. Профессионально прикладная физическая подготовка студентов технического вуза. Москва: Высшая школа 1985. $168 \mathrm{C}$.

23. Садовский ВА. Формирование двигательной готовности специалистов железнодо рожного транспорта в условиях просрессионально ориентированной системы физическо го воспитания [авторесерат]. Улан-Уде. 2012 $49 \mathrm{c}$

24. Сергієнко ВМ. Теоретико-методологічні основи контролю рухових здібностей студентської молоді у процесі фрізичного виховання [автореферат]. Київ. 2016. 40 с.
25. Теорія і методика фізичного виховання. Круцевич ТЮ, редактор. Київ: Олімпійська л-ра; 2008. Т. 1. 391 с.

26. Футорний СМ. Теоретико-методичн основи інноваційних технологій формування здорового способу життя студентів в процесі фізичного виховання [автореферат]. Київ 2015. 44 c.

27. Церковна ОВ. Професійно-прикладна фізична підготовка студентів технічних вищих навчальних закладів на основі факторно структури їх рухової та психофізіологічно підготовленості [автореферат]. Харків. 2007. $25 \mathrm{c}$

28. Чухланцева НВ. Оптимізація процесу фізичного виховання студентів транспортних спеціальностей на основі поглибленого кур су професійно-прикладної фрізичної підготовки [авторефрерат]. Харків. 2010. 22 с.

29. Юмашева Л, Філіпов М. Корекція порушень постави в процесі фізичного виховання студентів музичного вузу. Теорія і методика фізичного виховання і спорту. 2005;(2-3):110-3.

30. Яворський Al. Дослідження ефективності авторської програми прикладної фізич ної підготовки офіцерів-випускників кафедр підготовки офріцерів запасу. В: Єрмаков СС, редактор. Педагогіка, психологія та медико біологічні проблеми фізичного виховання спорту: зб. наук. праць. 2016;(2):72-7.

31. Aleshina A, Kolos N. Correction of functional irregularity of students' musculoskeleta systems in the physical training process. Physica education, sport and health culture in modern society. 2015;4(32):52-6.

32. Chernii V, Shevchenko 0 , Nievorova 0 Melnyk A, Kramarenko A, Nikonenko T. Develop ment of professionally important physical qualitie in engineering students. Revista romaneasca pentru educatie multidimensional. 2020;12(1):93-105

33. Kashuba V. Modern approaches to im proving body constitution of female student within physical education classes. Journal of Physical Education and Sport. 2017;(4). Art 277. Pp. 2472-76.

34. Kashuba V., Asauluk I., Dyachenko A. Peculiarities of the unit of practical application of correction technology of the students' physical condition in the process of vocational and applied physical training. Journal of Education, Health and Sport. 2017;7(8):Pp.1818-27. eISSN 2391-8306. URL: http://dx.doi.org/10.5281/zenodo.2549517; http: //ojs.ukw.edu.pl/index.php/johs/article/ view/6528.

35. Kashuba V., Asauluk I., Dyachenko A. The formation of theoretical knowledge of students in the discipline of «Physical Education» in the process of professional and applied physical training. Journal of Education, Health and Sport. 2017; Vol. 7. No. 5. P. 1054-65. elSSN 2391-8306. http:// dx.doi.org/10.5281/zenodo.2547839

36. Kashuba V., Asauluk I., Dyachenko A. To the question of use of health fitness in the process of professional and applied physical preparation of student youth. Journal of Education, Health an Sport. 2017; Vol. 7. No 7. P.1366-78. eISSN 2391 8306. http://dx.doi.org/10.5281/zenodo.2547968 http://ojs.ukw.edu.pl/index.php/johs/article/ view/6520

\section{LITERATURE}

1. Asauliuk 10. Theoretico-methodical bases of professionally-applied physical training of students of art specialties [dissertation] Kyiv. 2020. 562 p.
2. Bikmayev IA. Professional psychophysical training of students of the specialty «life safety» in physical education universities [dissertation] Omsk. 2004. 195 p.

3. Bondarenko IH. Means of professional and applied physical training in physical education of students-ecologists [abstract]. Dnipropetrovsk. 2009. 20 p.

4. Dotsenko I0. Assessment of psychophysical readiness of mining students for employment [author's abstract]. Kyiv. 2015. 24 p.

5. Dubynska OI, Salatenko IO. Applied issues of physical education of economic specialty students. Pedahohika, psykholohiia ta medyko-biolohichni problem fizychnoho vykhovannia i sportu (S.S. lermakova, editor). 2014;(5):19-23.

6. Dutchak M, Andreieva 0, Kateryna U._Foreign experience in organizing physical education for students of countries with a high level of involvement of the population in healthimproving physical activity. Teoriia i metodyka fizvykhovannia i sportu. 2018;(3):49-58.

7. Yegorychev A0. Theory and technology of management of psychophysical preparation of students for professional activity [dissertation] Yaroslavl. 2005.317 p.

8. Karabanov P0. Optimization of professional and applied physical training of future specialists of agro-industrial production [abstract]. Dnipro. 2017. 22 p.

9. Kyrylenko VM. Dynamics of changes in the level of professionally important qualities of cadets of higher military educational institutions of flight profile. Pedahohika, psykholohiia ta medyko-biolohichni problem fizychnoho vykhovannia i sportu (S.S. lermakova, editor). 2015;(6):10-3.

10. Krutsevych T, Pangelova N. Modern trends in physical education organization at higher education institutions. Sportyvnyi visnyk Prydniprovia. 2016;(3):109-14.

11. Liudovik TV.Professional and applied physical training of students studying in the field of «micro- and nanoelectronics» [abstract]. Lviv. 2016. $19 \mathrm{p}$

12. Moskalenko NV. Technology of forming valuable attitude of students to independent physical culture classes. Sportyvnyi visnyk Prydniprovia. 2016;(1):201-6.

13. Olkhovyi OM. Theoretico-methodical bases of physical training system for cadets of higher military institutions [author's abstract]. Kyiv. 2013. 38 p

14. Ostapenko I0. Professionally applied physical preparation of students of information and logical group of specialties [author's abstract]. Kyiv. 2015. 22 p.

15. Pangelova N, Zakharchenko H. Features of motives and needs of students in various sports games classes. Sportyvnyi visnyk Prydniprovia. 2011;(2):48-50.

16. Petrenko NV Optimizing physical and intellectual work capacity pf students of economic specialties by means of aqua fitness [dissertation]. Kyiv. 2015. 243 p.

17. Pylypei LP. Theoretico-methodical bases of professionally applied physical preparation of higher education institution students [abstract]. Ktiv. 2011. 40 p.

18. Pichurin VV. Psychological and psychophysical preparation as a constituent of educating the students of higher education institutions. Pedahohika, psykholohiia ta medykobiolohichni problem fizychnoho vykhovannia i sportu (S.S. Iermakova, editor). 2014;(11):44-8. Doi: $10.15561 / 18189172.2014 .1108$

19. Pichurin VV. Theoretico-methodical bases of psychophysical preparation of students of engi- 
neering specialties in the process of physical education. Dnipro: Svidler A.L.; 2017. 393 p.

20. Podlesnyi Ol. Self-control in physical education as a means of increasing motivation for professional and applied physical training of student drivers [abstract]. Kyiv. 2008. 22 p.

21. Prykhodko VV._On the need to determine the place of physical education in the reform of domestic higher education in the context of the competency approach. Sportyvnyi visnyk Prydniprovia. 2016;(1):215-20.

22. Rayevsky RT. Professionally applied physical preparation of technical institution students. Moscow: Vysshaya shkola; 1985. $168 \mathrm{p}$.

23. Sadovsky VA. Formation of motor fitness of railway transport specialists in the conditions of a professionally oriented system of physical education [abstract]. Ulan-Ude. 2012. 49 p.

24. Serhiienko VM. Theoretico-methodical bases of control for student youth motor skills during physical education [author's abstract]. Kyiv. 2016. $40 \mathrm{p}$.

25. Theory and methods of physical education. Krutsevych TI, editor. Kyiv: Olimpitska literatura; 2008. Vol. 1. $391 \mathrm{p}$.

26. Futornyi SM. Theoretico-methodical bases of innovation technologies for healthy life style formation in students during physical education[author's abstract]. Kyiv. 2015. 44 p.

27. Tserkovna OV. Professionally applied physical preparation of students of technical institutions based on factor structure of their motor and psychophysical fitness [author's abstract] Kharkiv. 2007. $25 \mathrm{p}$.

28. Chukhlantseva NV. Optimizing physical education process for students of transport specialties based on in-depth course of professionally applied physical training [author's abstract] Kharkiv. 2010. 22 p.

29. Yumasheva L, Filipov M. Correction of posture disorders in the process of physical education of medical students. Teoriia i metodyka fizvykhovannia i sportu. 2005;(2-3):110-3.

30. Yavorskyi Al. Study of the efficiency of author's program of applied physical training of graduates of military institutions. Pedahohika, psykholohiia ta medyko-biolohichni problem fizychnoho vykhovannia i sportu (S.S. Iermakova, editor). 2016;(2):72-7.

31. Aleshina A, Kolos N. Correction of functional irregularity of students' musculoskeletal systems in the physical training process. Physical education, sport and health culture in modern society. 2015;4(32):52-6.

32. Chernii V, Shevchenko O, Nievorova 0 , Melnyk A, Kramarenko A, Nikonenko T. Development of professionally important physical qualities in engineering students. Revista romaneasca pentru educatie multidimensional. 2020; 12(1):93-105

33. Kashuba V. Modern approaches to improving body constitution of female students within physical education classes. Journal of Physical Education and Sport. 2017;(4). Art 277. Pp. 2472-76.

34. Kashuba V., Asauluk I., Dyachenko A. Peculiarities of the unit of practical application of correction technology of the students' physical condition

in the process of vocational and applied physical training. Journal of Education, Health and Sport. 2017;7(8):Pp.1818-27. elSSN 2391-8306. URL: http://dx.doi.org/10.5281/zenodo.2549517; http: // ojs.ukw.edu.pl/index.php/johs/article/view/ 6528 .

35. Kashuba V., Asauluk I., Dyachenko A. The formation of theoretical knowledge of students in the discipline of «Physical Education» in the process of professional and applied physical training. Journal of Education, Health and Sport. 2017; Vol. 7. No. 5. P. 1054-65. elSSN 2391-8306. http:// dx.doi.org/10.5281/zenodo.2547839

36. Kashuba V., Asauluk I., Dyachenko A. To the question of use of health fitness in the process of professional and applied physical preparation of student youth. Journal of Education, Health and Sport. 2017; Vol. 7. No 7. P.1366-78. eISSN 2391 8306. http://dx.doi.org/10.5281/zenodo.2547968 http://ojs.ukw.edu.pl/index.php/johs/article/ view/6520

\section{ІНФОРМАЦІЯ ПРО АВТОРІВ}

Москаленко Наталія Василівна admin_infiz@ukr.net

Придніпровська державна академія фрізичної культури і спорту

Пічурін Валерій Васильович https://orcid: 0000-0002-3893-375X, valeriypichurin@gmail.com Дніпровський національний університет залізничного транспорту ім. академіка В. Лазаряна, 49010, Дніпро,вул. Лазаряна, 2

\section{INFORMATION ABOUT THE AUTHORS}

Moskalenko Natalya admin_infiz@ukr.net

Prydniprovsk State Academy of Physical Culture and Sport

Pichurin Valery https://orcid: 0000-0002-3893-375X, valeriypichurin@gmail.com Dnipro National University of Railway Transport named after Academician V. Lazaryan, 49010, Dnipro, Lazaryan str., 2

Надійшла 25.02.2021 